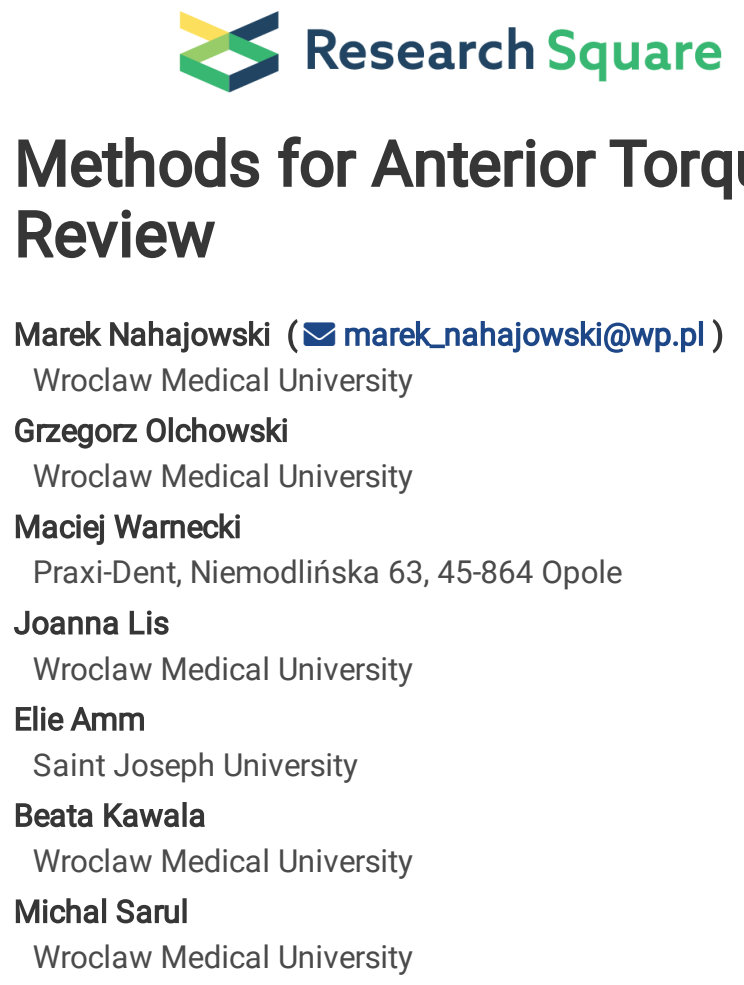

\title{
Methods for Anterior Torque Control during Retraction: A Systematic Review
}

\section{Research Article}

Keywords: teeth retraction, torque control, orthodontics

Posted Date: June 21st, 2021

DOI: https://doi.org/10.21203/rs.3.rs-556431/v1

License: (9) (1) This work is licensed under a Creative Commons Attribution 4.0 International License. Read Full License 


\section{Abstract}

\section{Background}

There are various methods to control the inclination of the incisors during retraction, but there is no evidence as to the advantages of some methods over others. The purpose of this systematic review and meta-analysis was to determine the effectiveness of the methods used to control torque during anterior teeth retraction.

\section{Methods}

In accordance with the PRISMA guidelines, the main research question was defined in the PICO format [P: patients with complete permanent dentition; I: the maxillary incisor torque after (I) and before (C) retraction with straight-wire appliance and different modes of torque control; $\mathrm{O}$ : statistically significant differences in torque values of the upper incisors after orthodontic treatment]. The MEDLINE, EMBASE, and Cochrane Central Register of Controlled Trials databases were searched for keywords combining: retraction orthodontics, torque control orthodontics, torque orthodontics, inclination orthodontics, torque control retraction. The articles were subjected to risk of bias and quality analyses with the ROBINS-I protocol and the modified Newcastle-Ottawa QAS, respectively. Meta-analyses were performed with both fixed and random effects models.

\section{Results}

13 articles were selected in which total number of 580 subjects took part. In all studies incisors were retroclined during retraction by $2.46^{\circ}$ (mean difference), which was statistically significant. Considering articles separately, differences in torque between the study group and the control group were statistically significant in 6 articles. The $Q$ statistic value was 36.25 with $p=.0003$ and $I^{2}=66.9 \%$ which indicate a high level of study heterogeneity.

\section{Conclusion}

Both properly performed corticotomy and en-masse retraction using orthodontic microimplants seem to be the most effective and scientifically validated methods of torque control. Further high-quality research is needed to perform better quality analyses and draw more reliable conclusions.

\section{Background}

Control of the anterior roots torque is a very important issue in orthodontic treatment. It allows stability of the normal interincisal angle, which in turn helps to support soft tissues thus securing a harmonious facial profile ${ }^{1-2}$. The discussed torque is also substantial for maintaining a healthy periodontium, which minimizes the risk of the tooth migration, recession, fenestration, or dehiscence in the front area of the dental $\operatorname{arch}^{1}$.

Predominantly, a necessity of mechanical controlling the incisor root torques occurs in treatment of moderate-to-severe dental crowding, bimaxillary protrusion, high-angle or Class II patients. These malocclusions usually call for extraction of the premolars, which precedes retraction of the canines. The spaces occurring mesially to the distalized canines make the incisors especially prone to uncontrolled tipping, namely: to retroclination or lingual tipping during their retraction, also referred as "rabbiting". Therefore, in order to avoid this side effect, various methods to control the torque during retraction of the anterior teeth have been proposed, such as brackets with an increased torque value, twisting of archwires, placement of Temporary Intraoral Skeletal Anchorage Devices (TISADs) enabling group distal movement of the "social six" (en-masse retraction), or a microimplant inserted between the maxillary incisors. Regardless reported variety of approaches supporting the root-torque control during space closure, evaluation of their efficiency is almost exclusively based on clinicians' individual experience.

Therefore, the purpose of this systematic review was to objectively determine the efficiency of different methods to control torque of the maxillary incisor roots during their orthodontic retraction, thus establishing, which of the investigated approaches deserve the highest recommendation for clinical practice

\section{Methods}

The systematic review was registered in the PROSPERO database under ID number CRD42021215408. 
The study was conducted according to PRISMA (Preferred Reporting Items for Systematic Reviews and Meta-Analyses) guidelines. The research design was defined in PICO format:

Population $(\mathrm{P})$ : patients with complete permanent dentition

Intervention (I): orthodontic extraction treatment with straight-wire appliance supported with additional method controlling the incisor roots torque

Comparison (C): incisor roots torque prior to intervention

Outcome (0): statistically significant/insignificant differences in torque values of the maxillary incisors before and after orthodontic treatment.

We searched the electronic databases: PubMed, EMBASE, and the Cochrane Central Register of Controlled Trials, entering following keywords:

- incisor retraction \& orthodontics

- incisor root torque control \& orthodontics

- root torque \& orthodontics

- incisor inclination \& orthodontics

- incisor root torque control \& retraction

Based on the information provided in the abstracts, articles were selected according to the following inclusion criteria: randomized clinical trials (RCTs) and controlled clinical prospective trials (CCTs) published within the last 10 years. Single case reports, case series, literature reviews, experimental studies, studies with limited data (including conference abstracts and journal letters), studies involving nonrepresentative group of patients (less than 10 individuals), studies on patients with syndromes and animal experiments were rejected. Articles in a language other than English and those unrelated to the topic of the planned study were also excluded.

Out of the selected full-text articles, those that did not provide the change in inclination of the maxillary incisors after orthodontic treatment were disqualified. Articles that did not report the number of patients who completed an orthodontic treatment were rejected as well.

Regarding the remaining articles, references were reviewed, and the following journals were manually searched: American Journal of Orthodontics and Dentofacial Orthopedics, International Orthodontics, Journal of Clinical Orthodontics, and the Angle Orthodontist.

The following data was extracted from the reviewed articles: year of publication, group size, characteristics of the study group and control group, method of the root torque control, the maxillary incisor roots torque before and after an orthodontic treatment, together with mean changes of these angular values (Table 1). 
Table 1

Data from articles

\begin{tabular}{|c|c|c|c|c|c|c|c|c|c|c|}
\hline Study & $\begin{array}{l}\text { Control } \\
\text { group }\end{array}$ & $\begin{array}{l}\text { Study } \\
\text { group }\end{array}$ & $\begin{array}{l}\text { Age of } \\
\text { participants } \\
\text { (yrs) }\end{array}$ & $\begin{array}{l}\text { Treatment } \\
\text { strategy }\end{array}$ & $\begin{array}{l}\text { Change in } \\
\text { the U1- } \\
\text { inclination } \\
\text { during the } \\
\text { observation } \\
\text { period }\left(^{\circ}\right)\end{array}$ & $\begin{array}{l}\text { SD } \\
\left({ }^{\circ}\right)\end{array}$ & $\begin{array}{l}\text { Median } \\
\text { difference } \\
\text { of U1- } \\
\text { inclination } \\
\text { between } \\
\text { groups } \\
\left(\mathrm{G} 1-\mathrm{G} 2,^{\circ}\right)\end{array}$ & $\begin{array}{l}\text { SE } \\
\text { (standard } \\
\text { error) }\end{array}$ & $p$ & $\begin{array}{l}\text { Contribution } \\
\text { for analysis } \\
\text { result (\%) }\end{array}$ \\
\hline \multicolumn{11}{|l|}{ RCTs } \\
\hline $\begin{array}{l}\text { Davoody } \\
\text { et al. } \\
(2012)\end{array}$ & $\begin{array}{l}\text { G1: } 15 \\
\text { (M5 } \\
\text { F10) }\end{array}$ & $\begin{array}{l}\text { G2: } \\
13 \\
(\mathrm{M} 7 \\
\mathrm{F} 6)\end{array}$ & $\begin{array}{l}\text { Median 17- } \\
18\end{array}$ & $\begin{array}{l}\text { G1: 2-step } \\
\text { retraction; } \\
\text { G2: } \\
\text { retraction } \\
\text { with TADs }\end{array}$ & $\begin{array}{l}\text { U1-X; G1: } \\
-10.63 ; \text { G2: } \\
-18.66\end{array}$ & $\begin{array}{l}\text { G1: } \\
9.9 \\
\text { G2: } \\
8.21\end{array}$ & 8.02 & 3.471 & .0207 & 3.14 \\
\hline $\begin{array}{l}\text { Al-Sibaie } \\
\text { and } \\
\text { Hajeer } \\
(2013)\end{array}$ & $\begin{array}{l}\text { G2: } 28 \\
(\mathrm{M} 12 \\
\text { F16) }\end{array}$ & $\begin{array}{l}\text { G1: } \\
28 \\
\text { (M9 } \\
\text { F19) }\end{array}$ & $\begin{array}{l}\text { Median 20- } \\
23\end{array}$ & $\begin{array}{l}\text { G1: } \\
\text { retraction } \\
\text { with TADs; } \\
\text { G2: 2-step } \\
\text { retraction } \\
\text { with TPA }\end{array}$ & $\begin{array}{l}\text { U1-Sn; G1: } \\
-5.03 ; \mathrm{G} 2: \\
-7.94\end{array}$ & $\begin{array}{l}\text { G1: } \\
3.39 \\
\text { G2: } \\
2.51\end{array}$ & 2.91 & .797 & .0003 & 12.75 \\
\hline $\begin{array}{l}\text { Sadeka } \\
\text { et al. } \\
(2019)\end{array}$ & $\begin{array}{l}\text { G1: } \\
\text { 14F }\end{array}$ & $\begin{array}{l}\mathrm{G} 2: \\
14 \mathrm{~F}\end{array}$ & $\begin{array}{l}\text { Median } \\
20+-2\end{array}$ & $\begin{array}{l}\text { G1: } \\
\text { retraction } \\
\text { with TADs, } \\
\text { buccal } \\
\text { mechanics; } \\
\text { G2: } \\
\text { retraction } \\
\text { with TADs, } \\
\text { lingual } \\
\text { mechanics }\end{array}$ & $\begin{array}{l}\text { U1-PP; G1: } \\
-4.41 ; \mathrm{G} 2: \\
-10.26\end{array}$ & $\begin{array}{l}\text { G1 } \\
2.33 \\
\text { G2: } \\
4.7\end{array}$ & 5.85 & 1.402 & 0 & 9.39 \\
\hline $\begin{array}{l}\text { Al-Imam } \\
\text { et al. } \\
(2019)\end{array}$ & $\begin{array}{l}\text { G2: } 20 \\
(\mathrm{M} 4 \\
\text { F16) }\end{array}$ & $\begin{array}{l}\text { G1: } \\
20 \\
\text { (M5 } \\
\text { F15) }\end{array}$ & $\begin{array}{l}\text { Median } 19.5 \\
(16-31)\end{array}$ & $\begin{array}{l}\text { G1: 2-step } \\
\text { retraction } \\
\text { with } \\
\text { corticotomy; } \\
\text { G2: 2-step } \\
\text { retraction } \\
\text { without } \\
\text { corticotomy }\end{array}$ & $\begin{array}{l}\text { U1-Sn; G1:- } \\
\text { 7.88; G2: } \\
-9.40\end{array}$ & $\begin{array}{l}\text { G1: } \\
2.28 \\
\text { G2: } \\
1.39\end{array}$ & 1.52 & 0.597 & .0109 & 13.78 \\
\hline $\begin{array}{l}\text { Chen et } \\
\text { al. } \\
(2020)\end{array}$ & $\begin{array}{l}\text { G2: } 32 \\
(\mathrm{M} 11 \\
\text { F21) }\end{array}$ & $\begin{array}{l}\text { G1: } \\
32 \\
\text { (M10 } \\
\text { F22) }\end{array}$ & $11-35$ & $\begin{array}{l}\text { G1: } \\
\text { retraction } \\
\text { with PASS; } \\
\text { G2: } \\
\text { retraction } \\
\text { with MBT }\end{array}$ & $\begin{array}{l}\text { G1: }-6.94 ; \\
\text { G2: }-11.76\end{array}$ & $\begin{array}{l}\text { G1: } \\
6.35 \\
\text { G2: } \\
7.65\end{array}$ & 4.82 & 1.758 & .0061 & 7.69 \\
\hline $\begin{array}{l}\text { Tunçer } \\
\text { et al. } \\
\text { (2017) }\end{array}$ & $\begin{array}{l}\text { G2: } 15 \\
\text { (M2 } \\
\text { F13) }\end{array}$ & $\begin{array}{l}\text { G1: } \\
15 \\
\text { (M2 } \\
\text { F13) }\end{array}$ & $14<$ & $\begin{array}{l}\text { G1: } \\
\text { retraction } \\
\text { with TADs } \\
\text { and } \\
\text { piezosurgery; } \\
\text { G2: } \\
\text { retraction } \\
\text { with TADs } \\
\text { without } \\
\text { piezosurgery }\end{array}$ & $\begin{array}{l}\text { U1/HRP; } \\
\text { G1: -8.87; } \\
\text { G2: -9.98 }\end{array}$ & $\begin{array}{l}\text { G1: } \\
5.38 \\
\text { G2: } \\
8.08\end{array}$ & 1.11 & 2.506 & .6579 & 5.07 \\
\hline $\begin{array}{l}\text { Xu et al. } \\
(2010)\end{array}$ & $\begin{array}{l}\text { G1: } 32 \\
(M 12 \\
\text { F20) }\end{array}$ & $\begin{array}{l}\text { G2: } \\
31 \\
\text { (M12 } \\
\text { F19) }\end{array}$ & $10-16$ & $\begin{array}{l}\text { G1: } \\
\text { retraction } \\
\text { with TADs; } \\
\text { G2: 2-step } \\
\text { retraction }\end{array}$ & $\begin{array}{l}\text { U1 ling } \\
\text { crown tipp.; } \\
\text { G1: -10.7; } \\
\text { G2: }-10.1\end{array}$ & $\begin{array}{l}\text { G1: } \\
5.1 \\
\text { G2: } \\
4.7\end{array}$ & -0.6 & 1.237 & .6276 & 10.28 \\
\hline
\end{tabular}




\begin{tabular}{|c|c|c|c|c|c|c|c|c|c|c|}
\hline Study & $\begin{array}{l}\text { Control } \\
\text { group }\end{array}$ & $\begin{array}{l}\text { Study } \\
\text { group }\end{array}$ & $\begin{array}{l}\text { Age of } \\
\text { participants } \\
\text { (yrs) }\end{array}$ & $\begin{array}{l}\text { Treatment } \\
\text { strategy }\end{array}$ & $\begin{array}{l}\text { Change in } \\
\text { the U1- } \\
\text { inclination } \\
\text { during the } \\
\text { observation } \\
\text { period }\left({ }^{\circ}\right)\end{array}$ & $\begin{array}{l}\text { SD } \\
\left({ }^{\circ}\right)\end{array}$ & $\begin{array}{l}\text { Median } \\
\text { difference } \\
\text { of U1- } \\
\text { inclination } \\
\text { between } \\
\text { groups } \\
\left(G 1-G 2,{ }^{\circ}\right)\end{array}$ & $\begin{array}{l}\text { SE } \\
\text { (standard } \\
\text { error) }\end{array}$ & $p$ & $\begin{array}{l}\text { Contribution } \\
\text { for analysis } \\
\text { result (\%) }\end{array}$ \\
\hline $\begin{array}{l}\text { Deepak } \\
\text { et al. } \\
(2014)\end{array}$ & $\begin{array}{l}\text { Gk: } 10 \\
\text { (sex } \\
\text { NR) }\end{array}$ & $\begin{array}{l}\text { G1: } \\
10 \\
\text { (sex } \\
\text { NR) }\end{array}$ & $14-25$ & $\begin{array}{l}\text { G1: } \\
\text { retraction } \\
\text { with TADs; } \\
\text { Gk: } \\
\text { retraction } \\
\text { with posted } \\
\text { wires and } \\
\text { springs from } \\
\text { first molars }\end{array}$ & $\begin{array}{l}\text { G1: -5.8; } \\
\text { Gk: -5.8 }\end{array}$ & $\begin{array}{l}\text { G1: } \\
1.3 \\
\text { Gk: } \\
1.3\end{array}$ & 0 & 0.581 & 1 & 13.86 \\
\hline $\begin{array}{l}\text { Koyama } \\
\text { et al. } \\
(2011)\end{array}$ & $\begin{array}{l}\text { G2: } 14 \\
\text { (M2 } \\
\text { F12) }\end{array}$ & $\begin{array}{l}\text { G1: } \\
14 \\
\text { (M1 } \\
\text { F13) }\end{array}$ & $\begin{array}{l}\text { Median } \\
24.9+-5\end{array}$ & $\begin{array}{l}\text { G1: } \\
\text { retraction } \\
\text { with TADs; } \\
\text { G2: } \\
\text { retraction } \\
\text { with a } \\
\text { headgear } \\
\text { appliance }\end{array}$ & $\begin{array}{l}\text { SN-U1; G1: } \\
-10.3 ; \text { G2: } \\
-11.1\end{array}$ & $\begin{array}{l}\text { G1: } \\
5.8 \\
\text { G2: } \\
5.9\end{array}$ & 0.8 & 2.211 & .7175 & 5.95 \\
\hline $\begin{array}{l}\text { Lee and } \\
\text { Kim } \\
(2011)\end{array}$ & $\begin{array}{l}\text { G1: } \\
\text { 20F }\end{array}$ & $\begin{array}{l}\text { G2: } \\
20 \mathrm{~F}\end{array}$ & $\begin{array}{l}\text { Median } \\
23.32\end{array}$ & $\begin{array}{l}\text { G1: } \\
\text { retraction } \\
\text { with a } \\
\text { headgear } \\
\text { appliance; } \\
\text { G2: } \\
\text { retraction } \\
\text { with TADs }\end{array}$ & $\begin{array}{l}\text { U1-PP; G1: } \\
-16.20 ; \mathrm{G} 2 \\
-19.13\end{array}$ & $\begin{array}{l}\text { G1: } \\
5.59 \\
\text { G2: } \\
6.61\end{array}$ & 2.93 & 1.936 & .1301 & 6.95 \\
\hline \multicolumn{11}{|l|}{ CTs } \\
\hline $\begin{array}{l}\text { Ruan et } \\
\text { al. } \\
(2018)\end{array}$ & $\begin{array}{l}\text { G1: } 10 \\
\text { (sex } \\
\text { NR) }\end{array}$ & $\begin{array}{l}\text { G1: } \\
19 \\
\text { (sex } \\
\text { NR) }\end{array}$ & $\begin{array}{l}\text { G1: } \\
\text { adolescents; } \\
\text { G2: adults }\end{array}$ & $\begin{array}{l}\text { G1, G2: } \\
\text { retraction } \\
\text { with TADs }\end{array}$ & $\begin{array}{l}\text { Tor1; G1: } \\
-9.82 ; \text { G2: } \\
-11.47\end{array}$ & $\begin{array}{l}\text { G1: } \\
8.97 \\
\text { G2: } \\
6.70\end{array}$ & 1.65 & 2.685 & .5389 & 4.61 \\
\hline $\begin{array}{l}\text { Zhao et } \\
\text { al. } \\
(2018)\end{array}$ & $\begin{array}{l}\text { G1: } \\
\text { 18F }\end{array}$ & $\begin{array}{l}\text { G2: } \\
21 F\end{array}$ & $15<$ & $\begin{array}{l}\text { G1: } \\
\text { retraction } \\
\text { with elastics } \\
\text { (TADs for } \\
\text { anchorage } \\
\text { control); G2: } \\
\text { retraction } \\
\text { with power } \\
\text { chains } \\
\text { (TADs for } \\
\text { anchorage } \\
\text { control) }\end{array}$ & $\begin{array}{l}\text { U1-Sn; G1: } \\
-8.84 ; \text { G2: } \\
-15.98\end{array}$ & $\begin{array}{l}\mathrm{G} 1 \\
8.53 \\
\mathrm{G} 2: \\
5.60\end{array}$ & 7.14 & 2.28 & .0017 & 5.73 \\
\hline $\begin{array}{l}\text { Jeea et } \\
\text { al. } \\
(2013)\end{array}$ & $\begin{array}{l}\text { G1: } \\
15 \mathrm{~F}\end{array}$ & $\begin{array}{l}\text { G2: } \\
16 \mathrm{~F}\end{array}$ & Median 21 & $\begin{array}{l}\text { G1: } \\
\text { retraction } \\
\text { with a } \\
\text { conventional } \\
\text { C-wire and } \\
\text { TADs; G2: } \\
\text { retraction } \\
\text { with a } \\
\text { preformed C- } \\
\text { wire and } \\
\text { TADs }\end{array}$ & $\begin{array}{l}\text { U1-Sn; G1: } \\
-13.77 ; \mathrm{G} 2: \\
-11.31\end{array}$ & NR & -2.46 & 7.482 & .7423 & .80 \\
\hline
\end{tabular}

\section{Risk of bias}

The risk of bias analysis was conducted for different articles using the Cochrane Collaboration tool. The following criteria were applied: random sequence generation, allocation concealment, blinding of participants and personnel, blinding of assessors, incomplete outcome data, selective reporting of outcomes, and other potential sources of bias. For a qualitative assessment, a modified Newcastle-Ottawa Quality Assessment Scale was used, consisted of three sections: 
1) Patient selection, where the following elements were assessed: a) representativeness of the group exposed to the studied factor, b) patient selection for the control group, c) source of data concerning individual patients, d) proving that studied effects did not occur at the beginning of the study. A maximum of 1 point was awarded for each subpoint, resulting in a possible score of 4 points.

2) Confounding factors, where it was assessed whether the control group was identical to the study group in terms of other factors that could possibly influence the outcomes. In that category, 0 to 2 points were awarded, depending on the significance of the confounding factors' influence.

3) Outcome assessment, which analyzed: a) blinding of assessors, b) duration of the observation period, and c) percentage of patients who completed the trial, enabling a maximum score of 3 points.

\section{Statistical analysis}

For each article, a statistical analysis was performed for the difference in mean changes in the inclination of the maxillary incisor between controls and the study group. Studies with a statistically significant difference were selected. The results were graphically presented using a forest plot. In addition, an analysis of the heterogeneity of the included studies was performed. To this end, the authors conducted a heterogeneity test based on the Q-statistics, and the $\mathrm{I}^{2}$ statistics were calculated. All calculations were performed using Statistica 13 PLM software (StatSoft Polska, Krakow, Poland).

\section{Results}

The keyword input yielded 3,154 abstracts. Forty-four articles were initially confirmed eligible for a systematic review and were analyzed in detail. Finally, 13 articles were selected, including 7 RCTs and 6 CCTs. A complete selection process is shown in Fig. 1.

\section{Group size}

The total number of studied subjects was 580 . The average group size was 20 patients. The largest groups were found in articles by Chen et al. $^{2}$ and Xu et al. ${ }^{3}-32$ individuals per group. The smallest groups were included in Deepak et al.'s ${ }^{4}$ study -10 subjects per group. The sizes of the study group and control group were identical in most studies (Table 1).

\section{Age and sex}

The age of patients varied significantly between the papers: from 10 years in the study by Xu et al. ${ }^{3}$ to 35 years in Chen et al. study ${ }^{2}$. Hence, some patients were treated before or during the growth spurt, while others were treated as adults. The studies by Sadeka et al. ${ }^{5}$, Lee et al. ${ }^{6}$, Jiao et al. ${ }^{7}$ and Jeea et al. ${ }^{8}$ involved women only. The studies by Deepak et al. ${ }^{4}$ and Ruan et al. ${ }^{9}$ lacked information concerning the patients' sex. In each of the remaining studies, the female group size was larger than the male group size (Table 1).

\section{Treatment strategy}

In all patients who underwent treatment, extractions of the maxillary premolars were performed to gain space for the retraction of incisors and canines. In 10 studies, maximal anchorage in the form of TISAD was applied in the study groups ${ }^{3-6,8-13}$. Other articles investigated the impact of changes in the width of the slot inclination in first upper molar brackets ${ }^{2}$, the use of corticotomy ${ }^{12,14}$, the application of intramaxillary elastics and power chains ${ }^{7}$, and the efficiency of en-masse retraction compared to 2 -step retraction ${ }^{3}$.

\section{Analysis of risk}

The results of assessing both the risk of bias in RCTs randomized clinical trials and the qualitative analysis of CCTs are shown in Tables 2 and 3. 
Table 2

Risk of bias assessment of RCTs

\begin{tabular}{|c|c|c|c|c|c|c|c|}
\hline Study & $\begin{array}{l}\text { Random } \\
\text { sequence } \\
\text { generation }\end{array}$ & $\begin{array}{l}\text { Allocation } \\
\text { concealment }\end{array}$ & $\begin{array}{l}\text { Blinding of } \\
\text { participants and } \\
\text { personnel }\end{array}$ & $\begin{array}{l}\text { Blinding of an } \\
\text { outcome } \\
\text { assessment }\end{array}$ & $\begin{array}{l}\text { Incomplete } \\
\text { outcome } \\
\text { data }\end{array}$ & $\begin{array}{l}\text { Selective } \\
\text { reporting }\end{array}$ & $\begin{array}{l}\text { Other } \\
\text { bias }\end{array}$ \\
\hline $\begin{array}{l}\text { Al-Sibaie and } \\
\text { Hajeer (2013) }\end{array}$ & Low & Low & High & Low & Low & Low & Low \\
\hline $\begin{array}{l}\text { Davoody et } \\
\text { al. (2012) }\end{array}$ & Low & Low & High & Unclear & Low & High & Low \\
\hline $\begin{array}{l}\text { Sadeka et al. } \\
\text { (2019) }\end{array}$ & Low & Low & High & High & Low & Low & Unclear \\
\hline $\begin{array}{l}\text { Al-Imam et al. } \\
(2019)\end{array}$ & Low & Low & High & Low & Low & Low & Low \\
\hline $\begin{array}{l}\text { Chen et al. } \\
(2020)\end{array}$ & Low & Low & High & Low & Low & Moderate & Unclear \\
\hline $\begin{array}{l}\text { Tunçer et al. } \\
(2017)\end{array}$ & Moderate & Low & High & Low & Low & Moderate & Low \\
\hline $\begin{array}{l}\text { Xu et al. } \\
\text { (2010) }\end{array}$ & Low & Low & High & Low & Low & Low & Unclear \\
\hline
\end{tabular}

Table 3

The quality assessment of CCTs according to the modified Newcastle-Ottawa Scale

\begin{tabular}{|llll|}
\hline Study & Selection & Comparability & Outcome assessment \\
\hline Deepak et al. (2014) & 4 & 2 & 2 \\
\hline Lee and Kim (2011) & 4 & 2 & 2 \\
\hline Koyama et al. (2011) & 4 & 2 & 2 \\
\hline Ruan et al. (2018) & 3 & - & 1 \\
\hline Zhao et al. (2018) & 3 & - & 2 \\
\hline Jeea et al. (2013) & 3 & - & 2 \\
\hline
\end{tabular}

\section{Major parameter: change in the maxillary incisor roots torque}

In all studies, the incisors experienced lingual tipping during retraction, i.e., there was a vestibular root torque. The mean value of torque change in the study groups was $10.46^{\circ}$. The largest torque change of the incisors $\left(19.13^{\circ}\right)$ was reported by Lee et al. ${ }^{6}$, in the group where microimplants were used. Completely different results were obtained by Sadeka et al. ${ }^{5}$, who, after using microimplants for retraction on the vestibular side, found the smallest torque change in incisors: $4.41^{\circ}$ (Table 1 ).

After taking all studies into account, the mean difference in the change in the upper incisor inclination between the control group and the study group was $2.46^{\circ}$, which was statistically significant $(p=.0003)$. The highest discrepancy between groups was observed in the study by Davoody et $\mathrm{al}^{10}$. In contrast, no discrepancy between groups was observed in the study by Deepak et al. ${ }^{4}$ (Table 1$)$.

\section{The efficacy of methods for torque control of the upper incisor}

Out of 13 articles included in the statistics, the differences in torque between the study group and the control group were statistically significant $(p=.05)$ in 6 articles. The results of the conducted analysis are shown using a forest plot (Fig. 2).

The findings of statistically significant studies are presented below, from the highest to the lowest study significance (Table 4): 
Table 4

Most efficient treatment strategies of anterior torque control during retraction

\begin{tabular}{|c|c|c|c|c|}
\hline Study & Treatment strategy & $\begin{array}{l}\text { Median difference of U1- } \\
\text { inclination between groups } \\
\left(\mathrm{G} 1-\mathrm{G} 2,^{\circ}\right)\end{array}$ & $\mathbf{p}$ & $\begin{array}{l}\text { Contribution } \\
\text { for analysis } \\
\text { result (\%) }\end{array}$ \\
\hline $\begin{array}{l}\text { Al-Imam et } \\
\text { al. (2019) }\end{array}$ & $\begin{array}{l}\text { G1: 2-step retraction with corticotomy; G2: 2-step retraction } \\
\text { without corticotomy }\end{array}$ & 1.52 & .0109 & 13.78 \\
\hline $\begin{array}{l}\text { Al-Sibaie } \\
\text { and Hajeer } \\
(2013)\end{array}$ & G1: retraction with TADs; G2: 2-step retraction with TPA & 2.91 & .0003 & 12.75 \\
\hline $\begin{array}{l}\text { Sadeka et } \\
\text { al. (2019) }\end{array}$ & $\begin{array}{l}\text { G1: retraction with TADs, buccal mechanics; G2: retraction } \\
\text { with TADs, lingual mechanics }\end{array}$ & 5.85 & 0 & 9.39 \\
\hline $\begin{array}{l}\text { Chen et al. } \\
(2020)\end{array}$ & G1: retraction with PASS; G2: retraction with MBT & 4.82 & .0061 & 7.69 \\
\hline $\begin{array}{l}\text { Zhao et al. } \\
(2018)\end{array}$ & $\begin{array}{l}\text { G1: retraction with elastics (TADs for anchorage control); G2: } \\
\text { retraction with power chains (TADs for anchorage control) }\end{array}$ & 7.14 & .0017 & 5.73 \\
\hline $\begin{array}{l}\text { Davoody et } \\
\text { al. (2012) }\end{array}$ & G1: 2-step retraction; G2: retraction with TADs & 8.02 & .0207 & 3.14 \\
\hline
\end{tabular}

- Al-Imam et al ${ }^{14}$ : showed that corticotomy during the retraction of incisors reduces their lingual tipping by an average of $1.5^{\circ}$ compared to no surgically assisted retraction.

- Al-Sibaie et $\mathrm{al}^{11}$ : showed that en masse retraction using TISADs results in lingual tipping of in the incisors by an average of $2.9^{\circ}$ smaller compared to that with traditional 2-step retraction.

- Sadeka et $\mathrm{al}^{5}$ : showed that en masse retraction using microimplants and archwires on the vestibular side results in a reduction of the maxillary incisor lingual tipping by an average of $5.85^{\circ}$ compared to that when en masse retraction was conducted with lingual approach and microimplants placed on the palate.

- Chen et al ${ }^{2}$ : showed that patients treated with the PASS system demonstrated lingual tipping of the maxillary incisor by an average of $4.8^{\circ}$ smaller than during retraction in patients treated with the MBT system.

- Zhao et $\mathrm{al}^{7}$ : showed that the use of intra-maxillary elastics during incisor retraction results in lingual tipping of the maxillary incisors by an average of $7.14^{\circ}$ smaller compared to that with power chain use during retraction.

- Davoody et al ${ }^{10}$ : showed that traditional 2-step retraction using an additional intrusion archwire results in lingual tipping of the maxillary incisors by an average of $8^{\circ}$ smaller compared to that with en masse retraction supported by TISADs.

The $Q$ statistic value was 36.25 with $p=.0003$ and $\mathrm{I}^{2}=66.9 \%$. These data indicate a high level of study heterogeneity. This is most likely due to the various orthodontic techniques applied in individual studies.

\section{Discussion}

\section{Risk of bias}

The risk associated with randomization was considered low in most articles because of the detailed, rigorous randomization methods used in those studies. Only Tunçer et al. ${ }^{12}$ defined the risk of bias in their article as moderate because randomization was not performed in a fully objective manner but by individual determination of patient eligibility based on met criteria.

The risk associated with disclosure of the group assignment was considered low in all RCTs due to the use of opaque, sealed envelopes or other equivalent randomization methods.

The use of specific treatment methods and the differences between them were known to both study participants and clinicians. Patients were aware of their participation in the study and signed a consent form before the treatment. For this reason, blinding of participants and personnel to treatment status was impossible, and the risk of bias in that criterion was defined as high. 
Although blinding of participants was impossible, the overall risk of bias was reduced in some studies by blinding of assessors during the outcome analysis. In the articles by

Al-Sibaie et al. ${ }^{11}$, Al-Imam et al. ${ }^{14}$, Chen et al. ${ }^{2}$ and Tunçer et al. ${ }^{12}$, the assessor was not directly involved in the study and did not know its purpose; hence, the risk of bias was considered low. In the article by Sadeka et al. ${ }^{5}$, the assessor could easily define the purpose of the study (patients treated with labial or lingual appliances); thus, blinding was not possible, and the risk was considered high. In turn, the study by Davoody et al. ${ }^{10}$ did not provide any information concerning the blinding of assessors. However, it was stressed that the assessors could easily identify patients in each group based on an analysis of cephalograms (presence or absence of microimplants). A similar risk may have occurred in Al-Sibaie et al.'s study ${ }^{11}$. However, the authors explicitly stressed the blinding of assessors in that study. As it was difficult to determine the actual effect on bias, the risk in Davoody et al. ${ }^{10}$ article was finally defined as unclear.

In all studies, a complete set of data was obtained from patients and analyzed. Therefore, the risk in that category was considered low.

In Davoody et al. ${ }^{10}$ and Chen et al. ${ }^{2}$ articles, the authors stressed the possibility of attrition bias. In the first study, the loss of participants was approximately $30 \%$, and in the second study, it was approximately $6 \%$. Hence, the risk of selective reporting in Davoody et al. ${ }^{10}$ article was defined as high, while in Chen et al. ${ }^{2}$ article, it was defined as moderate. In that category, the article by Tunçer et al. ${ }^{12}$ was also of moderate risk. The reason was selectivity during the eligibility of participants for the study.

Additional potential sources of bias were identified in several studies. In Sadeka et al. ${ }^{5}$ article, the authors emphasized that a different vertical position of microimplants in the study groups, which was not taken into account during the outcome analysis, may have influenced the inclination of the upper incisors. In contrast, Chen et al. ${ }^{2}$ considered the impact of different anchoring methods used in individual patients to be a potential source of error in the results. Xu et al. ${ }^{3}$ stressed that patient treatment was conducted according to clinical standards, i.e., it was frequently tailored to the individual patient's needs and modified with the course of therapy. Therefore, direct comparison of specific treatment methods was not possible, which may have affected the lower statistical significance of the results obtained. Tunçer et al. ${ }^{12}$ pointed to the fact that the collection of patients' molecular samples began too late from the start of the trial and that the subsequent samples were collected at too-large intervals. In that case, however, those measurements were not relevant to our analysis. Finally, given the difficulty in determining the true impact of those limitations on the obtained results, the risk in the studies by Sadek et al. ${ }^{5}$, Chen et al. ${ }^{2}$ and Xu et al. ${ }^{3}$ was considered unclear.

The articles by Deepak et al. ${ }^{4}$, Lee et al. ${ }^{6}$ and Koyama et al. ${ }^{13}$ received 4 points (maximum) for the patient selection criterion. The remaining articles (Ruan et al. ${ }^{9}$, Jeea et al. ${ }^{8}$ ) lost 1 point due to the lack of controls. In terms of confounding factors, also due to the lack of controls, the articles by Ruan et al. ${ }^{9}$ and Jeea et al. ${ }^{8}$ received no points, whereas the remaining articles were given the maximum score ( 2 points). Regarding the last criterion (assessment of study effects), all articles lost 1 point due to the lack of assessor blinding. Moreover, the study by Ruan et al. ${ }^{9}$ lost 1 point due to a significant reduction in the number of patients confirmed eligible for the outcome analysis compared to the initial group size. Ultimately, the abovementioned study received 1 point for that category.

\section{Outcome analysis}

There are many different methods for torque control during anterior retraction; however, most of them were not sufficiently analyzed; hence, their efficiency is not fully validated. According to the present systematic review, not all torque control methods differ in terms of efficiency in a statistically significant way.

Among the torque control methods presented in this systematic review, it is worth examining those with the greatest statistically validated efficacy.

The use of corticotomy during retraction significantly reduces the lingual tipping of the maxillary incisors ${ }^{14}$, and the technique for corticotomy may be significant for torque control, that is, incisions should be made on both the vestibular and palatal sides. In Tunçer et al.'s ${ }^{12}$ study, where incisions were made only on the vestibular side, no statistically significant difference in torque loss was obtained compared to that in controls.

The use of TISADs during retraction also significantly reduces the lingual tipping (torque loss) of the maxillary incisors. This is because a vector of force used for retraction moves closer to the center of resistance of the retracted teeth than, for example, during traditional retraction, where the force is applied to maxillary molar brackets. Furthermore, traditional retraction is frequently performed in two steps, which may further influence the greater retroclination of incisors. This is confirmed by Sibaie et al. ${ }^{11}$. 
When retracting the anterior teeth, it is more advantageous to use vestibular mechanics than lingual mechanics ${ }^{5}$. In the latter, the force vector lies farther from the center of resistance of the retracted segment, which makes it more retruded.

The use of methods such as an intrusion archwire ${ }^{5,10}$ or the PASS system ${ }^{2}$ during incisor retraction should also be mentioned. In molar brackets, the PASS system has an additional slot with a $25^{\circ}$ inclination. The insertion of an additional archwire into that slot and its attachment to incisors has a similar effect to the use of an intrusion archwire - it strengthens the anchorage in the molar area and causes intrusion of incisors as well as their protrusion, thus increasing torque control during retraction. In the studies, an intrusion archwire was used both in combination with microimplants (Sadeka et al. ${ }^{5}$ ) and without microimplants (Davoody et al. ${ }^{10}$ ), obtaining better torque control results when skeletal anchorage was included. Nevertheless, the sole application of the intrusion archwire during retraction (Davoody et al. ${ }^{10}$ ) turned out to be more effective for torque control than isolated skeletal anchorage (Al-Sibaie et al. ${ }^{11}$ ). This highlights the role of vertical dimension control during retraction in maintaining the correct incisor torque.

The use of intra-maxillary elastics also results in less lingual tipping of incisors during retraction than, for example, the use of a power chain for this purpose 7 . This difference is probably a result of the much lower force acting on the anterior segment when using intra-maxillary elastics (approx. $100 \mathrm{~g}$ ) instead of a power chain (approx. $250 \mathrm{~g}$ ).

The influence of age on the degree of incisor inclination control is probably small, as suggested by Ruan et al. ${ }^{9}$. Although the retroclination of incisors in that study was greater in the adult group, there was no statistically significant difference.

The statistical analysis showed that the use of additional elements that control the torque resulted in less lingual tipping of incisors during extraction than the closure of dental gaps without using those methods (Table 4). Nevertheless, not all methods were equally effective. The greatest difference between controls and the group treated with assisted torque control was shown in the case of the traditional 2-step retraction with the use of an additional intrusion archwire (Table 4). When comparing the efficiency of torque control during en-masse retraction across studies and ranking it from highest to lowest, the following order of studies was obtained: Sadeka et al. ${ }^{5}, Z^{2}$ ao et al. ${ }^{7}$, Chen et al. ${ }^{2}$, Al.-Sibaie et al. ${ }^{11}$ and Al-Imam et al. ${ }^{14}$ (Table 1). However, it should be noted that the scientific credibility of those studies, ranked from largest to smallest, was characterized by a different order of the studies: Al-Imam et al. ${ }^{14}$, Al-Sibaie et al. ${ }^{11}$, Chen et al. ${ }^{2}$, Sadeka et al. ${ }^{5}$, Davoody et al. ${ }^{10}$ and Zhao et al. ${ }^{7}$ (Table 2,3$)$.

The influence on the aggregate outcome of the statistical analysis also varied. Ranking from the highest aggregate result, the order of the studies was as follows: Al.-Imam et al. ${ }^{14}$, Al-Sibaie et al. ${ }^{11}$, Sadeka et al. ${ }^{5}$, Chen et al. ${ }^{2}$, Zhao et al. ${ }^{7}$ and Davoody et al. ${ }^{10}$ (Table 4 ). In summary, the outcomes of studies proving the high efficiency of torque control are, alas, frequently associated with low statistical reliability.

\section{Limitations}

Only articles written in English within the past 10 years were taken into consideration, which may have had an impact on the risk of publication bias. Moreover, the number of clinical trials (RCTs and CCTs) analyzing the addressed topic was limited. Only those studies that provided torque values both before and after treatment were taken into account.

In studying the efficiency of different retraction methods, the presence of a control group is of great importance. By definition, that group should not be subjected to treatment. Therefore, the control group cannot be established during the torque examination because it is impossible, i.a., due to ethical reasons, to abandon treatment after extraction for orthodontic indications. Therefore, the present study is a comparison of different methods of torque control. During the process of article selection, some clinical trials were considered equivalent to the controlled trials because the results presented a comparison of study groups despite differences in the article description. The review also included one article that was a retrospective study but met the requirements for CCTs. The statistical analysis proved that in many articles, the significant SD value, in the absence of large study and control groups, casts doubt on the reliability of the results obtained. This explains the need for further studies, especially RCTs with more homogeneous groups of sufficiently large size.

\section{Conclusions}

The analyzed studies show that either performing corticotomy or using orthodontic microimplants are the most effective and scientifically validated methods of the incisor torque control during en-masse retraction. Statistically significant efficacy of these two protocols applied separately was proven in randomized clinical trials with a low risk of bias ${ }^{11,14}$. The use of both vestibular mechanics and an additional slot in molar brackets, which provides an effect similar to that caused by an intrusion archwire, was investigated in studies with an unclear risk of bias, where various factors may have affected the reliability of the results $2,5,10$. In contrast, the use of light force of intra-maxillary 
elastics was only analyzed in a nonrandomized clinical trial. Therefore, the conclusions of the present study should be interpreted with caution (Table 3). The age of the patients seems to be irrelevant to torque control ${ }^{9}$.

Although the incisors were retroclined after retraction in all studies, it should be noted that extraction is frequently performed in the case of excessive flaring of incisors. Hence, treatment aims to partially upright the incisors; thus, their slight lingual tipping cannot be treated as a lack of torque control, provided that it is not excessive. To provide a definitive answer to the question concerning the method that most effectively controls torque during retraction, further high-quality research - primarily RCTs with clearly defined methodology - is needed to perform better quality analyses and draw more reliable conclusions.

\author{
Abbreviations \\ PRISMA - Preferred Reporting Items for Systematic Reviews and Meta-Analyses \\ PICO - Population, Intervention, Comparison, Outcome \\ RCT- randomized clinical trial, \\ CCT- controlled clinical prospective trial
}

ROBINS-I - Risk of Bias In Non-randomized Studies of Interventions

QAS - Quality Assessment Scale

\title{
Declarations
}

\section{Ethics Approval and Consent to Participate:}

not applicable

\section{Consent for Publication:}

not applicable

\section{Availability of Data and Materials:}

the datasets used and/or analyzed during the current study are available from the corresponding author on reasonable request.

\section{Competing Interests:}

The authors declare that they have no competing interests

\section{Funding:}

none

\section{Authors' Contributions:}

MN and GO collected the data and were major contributors in writing the manuscript. MN, GO, and JL analyzed and interpreted the data. MN, GO, MW and MS created the tables and prepared the references list. All the authors performed the critical revision and final approval of the article.

\section{Acknowledgments:}

not applicable 


\section{References}

1. Coskun I, Kaya B. Appraisal of the relationship between tooth inclination, dehiscence, fenestration, and sagittal skeletal pattern with cone beam computed tomography. Angle Orthod. 2019;89:544-551. doi:10.2319/050818-344.1

2. Chen $H$, Han B, Jiang R, et al. PASS versus $M_{B}{ }^{\mathrm{Tm}}$ for evaluation of anchorage control in three-dimensional measurements: a randomized controlled trial. Eur J Orthod. 2021;43:113-119. doi:10.1093/ejo/cjaa021

3. Xu TM, Zhang X, Oh HS, Boyd RL, Korn EL, Baumrind S. Randomized clinical trial comparing control of maxillary anchorage with 2 retraction techniques. Am J Orthod Dentofac Orthop. 2010;138:544

.e1-544.e9

. doi:10.1016/j.ajodo.2009.12.027

4. Victor D, Prabhakar R, Karthikeyan MK, et al. Effectiveness of mini implants in three-dimensional control during retraction - A clinical study. J Clin Diagnostic Res. 2014;8:227-232. doi:10.7860/JCDR/2013/7801.4066

5. Sadek MM, Sabet NE, Hassan IT. Type of tooth movement during en masse retraction of the maxillary anterior teeth using labial versus lingual biocreative therapy in adults: A randomized clinical trial. Korean J Orthod. 2019;49:381-392. doi:10.4041/kjod.2019.49.6.381

6. Lee A-Y, Kim YH. Comparison of Movement of the Upper Dentition According to Anchorage Method: Orthodontic Mini-Implant versus Conventional Anchorage Reinforcement in Class I Malocclusion. ISRN Dent. 2011;2011:1-7. doi:10.5402/2011/321206

7. Li J, Zhao Y, Li H, Li H, Lei L. Effects of force magnitude on torque control in the correction of bimaxillary protrusion with mass retraction. J Orthod Sci. 2018;7:1-13. doi:10.4103/jos.JOS_65_17

8. Jee $\mathrm{JH}, \mathrm{Ahn} \mathrm{HW}$, Seo KW, et al. En-masse retraction with a preformed nickel-titanium and stainless steel archwire assembly and temporary skeletal anchorage devices without posterior bonding. Korean J Orthod. 2014;44:236-245. doi:10.4041/kjod.2014.44.5.236

9. Ruan MJ, Chen G, Xu TM. Comparison of orthodontic tooth movement between adolescents and adults based on implant superimposition. PLoS One. 2018;13:1-14. doi:10.1371/journal.pone.0197281

10. Davoody AR, Posada L, Utreja A, et al. A prospective comparative study between differential moments and miniscrews in anchorage control. Eur J Orthod. 2013;35:568-576. doi:10.1093/ejo/cjs046

11. Al-Sibaie S, Hajeer MY. Assessment of changes following en-masse retraction with mini-implants anchorage compared to two-step retraction with conventional anchorage in patients with class II division 1 malocclusion: A randomized controlled trial. Eur $J$ Orthod. 2014;36:275-283. doi:10.1093/ejo/cjt046

12. Tunçer NI, Arman-Özçirpici A, Oduncuoğlu BF, Göçmen JS, Kantarci A. Efficiency of piezosurgery technique in miniscrew supported enmasse retraction: A single-centre, randomized controlled trial. Eur J Orthod. 2017;39:586-594. doi:10.1093/ejo/cjx015

13. Koyama I, lino S, Abe Y, Takano-Yamamoto T, Miyawaki S. Differences between sliding mechanics with implant Anchorage and straightpull headgear and intermaxillary elastics in adults with bimaxillary protrusion. Eur J Orthod. 2011;33:126-131. doi:10.1093/ejo/cjq047

14. Al-Imam GMF, Ajaj MA, Hajeer MY, Al-Mdalal Y, Almashaal E. Evaluation of the effectiveness of piezocision-assisted flapless corticotomy in the retraction of four upper incisors: A randomized controlled clinical trial. Dent Med Probl. 2019;56:385-394. doi:10.17219/dmp/110432

\section{Figures}




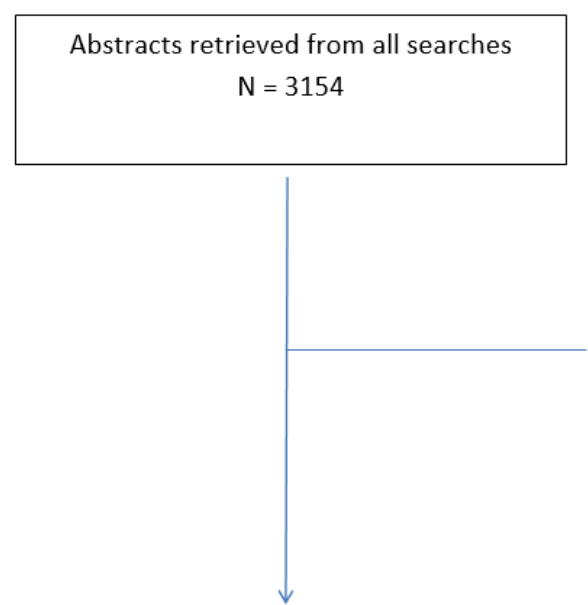

Full-text articles retrieved for more detailed analysis

$$
\mathrm{N}=44
$$

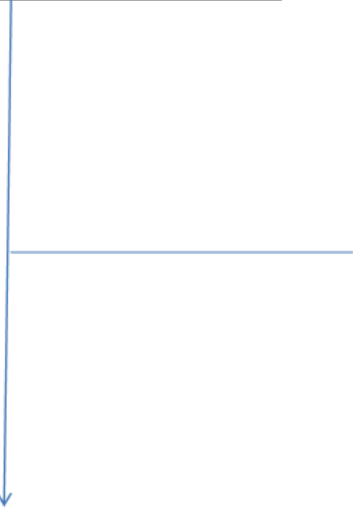

Relevant full-text articles included in the systematic review

$\mathrm{N}=13$

Records failed to meet inclusion criteria:
\[ \begin{array}{c}\text { Not relevant } \\ \text { Case reports } \\ \text { Case series } \\ \text { Experimental studies } \\ \text { Language different from English } \\ \text { Review articles } \\ \mathrm{N}=3110\end{array} \]

Records failed to meet inclusion criteria:

Sample size per group $<10$ Lack of control group

Lack of outcome data concerning incisor torque value

$$
\mathrm{N}=31
$$

\section{Figure 1}

The PRISMA flow diagram 
Incisor roots torque

Meta-analysis: D (difference in means); Variable effect; $95 \% \mathrm{Cl}$

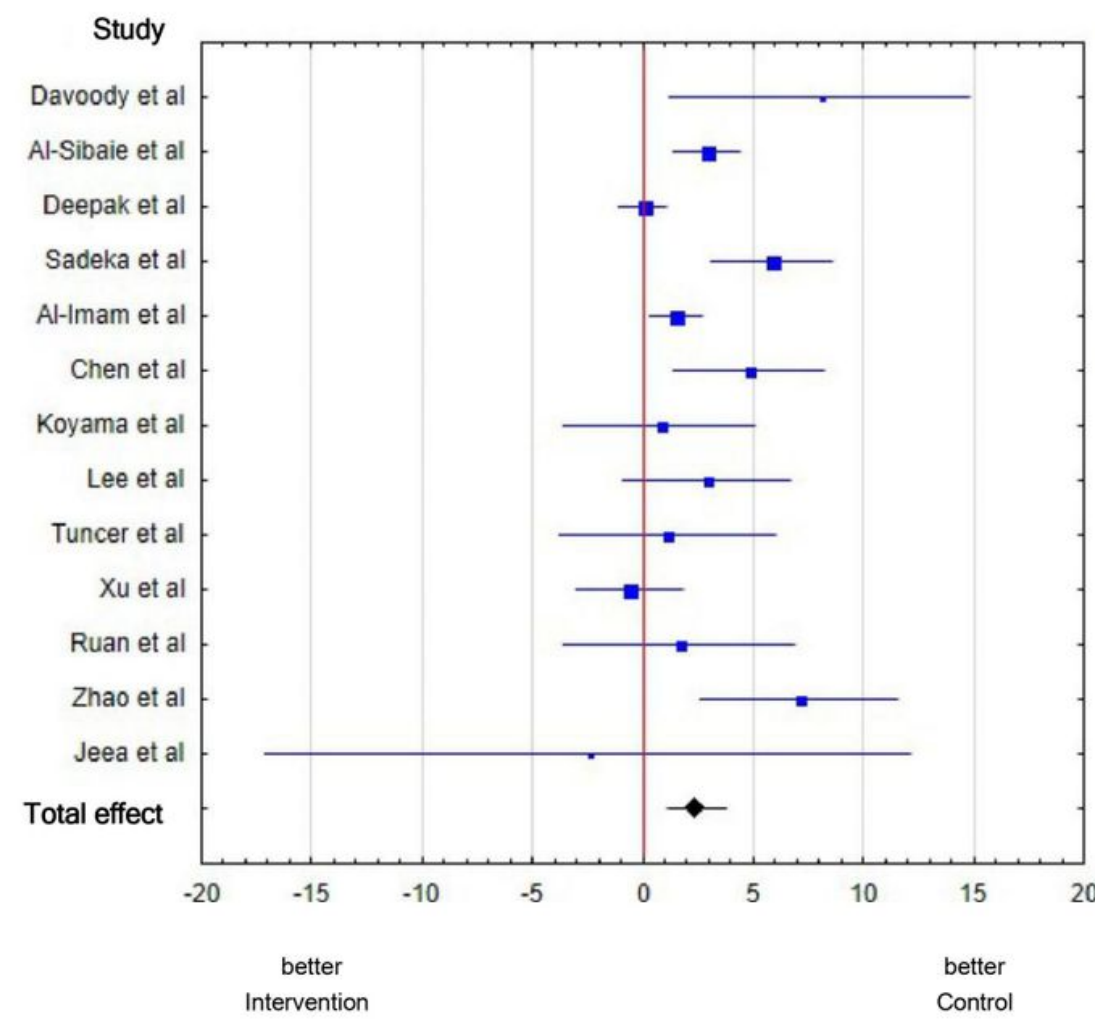

D $\quad \mathrm{Cl}$ lower $\mathrm{Cl}$ upper Percentage [\%]

$8,030 \quad(1.228 \quad 14.832) \quad 3.14 \%$

$2,910 \quad(1.348 \quad 4.472) \quad 12.75 \%$

$0,000 \quad(-1.139 \quad 1.139) \quad 13.86 \%$

$5,850 \quad(3.102 \quad 8.598) \quad 9.39 \%$

$\begin{array}{lll}1,520 & (0.350 \quad 2.690) & 13.78 \%\end{array}$

$4,820 \quad(1.375 \quad 8.265) \quad 7.69 \%$

$0,800 \quad(-3.534 \quad 5.134) \quad 5.95 \%$

$2,930 \quad(-0.864 \quad 6.724) \quad 6.95 \%$

$1,110 \quad(-3.802 \quad 6.022) \quad 5.07 \%$

$\begin{array}{lll}-0,600 & (-3.024 \quad 1,824) \quad 10.28 \%\end{array}$

$1,650 \quad(-3.613 \quad 6.913) \quad 4.61 \%$

$7,140 \quad(2.671 \quad$ II, 609) $5.73 \%$

$\begin{array}{lll}-2,460 \quad(-17.124 & 12.204) & 0.80 \%\end{array}$

$2,464 \quad\left(\begin{array}{lll}1.113 & 3.814\end{array}\right) \quad 100.00 \%$

\section{Figure 2}

The mean difference of the incisor inclination change between study and control groups. 